\title{
Traditional and Christian concepts of disease and healing among the Manianga
}

M M Mulemfo

Ph D-student, Department of Missiology, Faculty of Theology (Sec B) University of Pretoria

\begin{abstract}
The Manianga of Zaire believed, and still believe, in a Supreme Being called 'Nzambi Mpungu'. He is the origin of all health care, including medicinal plants. According to traditional understanding, God uses the ancestors - 'bakulu' - to reveal these plants and their use to healers for the sake of the living community. The belief in the ancestors as mediators between God and people has been dispelled by missionaries. However, there are some Manianga who, despite their Christianity, still believe that the ancestors have an important role to play in the living community. It is the task of the Church to demonstrate a biblical healing ministry amid these conflicting approaches. This implies not the banning of the practice, but its improvement according to the message of Jesus Christ. The evangelical community of Zaire should create a climate of dialogue to promote effective collaboration between the traditional healers and modern practitioners.
\end{abstract}

\section{INTRODUCTION}

It could be said that the quest for health care has been a major concern for African people. This is true not only of Africans but of all human societies. People have used their knowledge to seek and find all the skills which are important to maintain the health of the community. Health care has been considered to some extent to be at the centre of life, and without it the social life of the community would be threatened and unbalanced.

* The theme of this article was the topic which I submitted in part fulfilment of the requirements for the degree of 'Master of Theology', in the subject 'Missiology', University of South Africa (June 1993). Therefore, I would like to refer readers to the dissertation for more information. 
The seeking of health care involves the whole community. Healing is thus considered to be the concern of the whole society. If someone is ill all the members of a community feel psychologically and to some extent spiritually the pains of being ill. This attitude expresses real communion and a true spirit of compassion which binds them together.

Healing as a common concern gives Africans an opportunity to commit themselves to the culture of communal solidarity. The people are bound to their cultural lineages or descent groups. The strong sense of human feeling and communal solidarity forbids people to live outside their social bounderies, rules, responsibilities and commitments. By doing what is contrary to society's rules a person exposes himself/herself to lifethreatening risks and total rejection by the whole community. The general conception of the person in Africa is that the person finds his/her full human significance within the social structures. In this regard, Setiloane (1976:32-33) comments that the significant level or organisation is not that of individual men and women but of man-incommunity. Hence, their common usual everyday expression, Motho ke motho ka batho (man is man through, with and in association with other persons). Individuals are cherished. But they find their significance' only in a particular pattern of social behaviour'. In Kimanianga, one would say Bantu bole bukaka musongo - this means, literally 'two are people but loneliness is a sickness'. It is from the same perspective that Bussia (in Brookman-Amissah 1984:150) comments, 'the essence of (the African's) humanity is the membership in a kinship group, it is his integration within it that makes him a human being and gives him his status by reference to which his role within the community is defined'.

Hence, communal solidarity is the foundation of African society. It is in this understanding that the people within the community are supposed to transmit their medical knowledge to those who are capable of putting them into practice with the aim of helping the whole community. The theological interpretation of African culture would affirm the argument that there is a certain reflection of the love of God within the community. For if one believes in the general revelation of God throughout the world, that $\mathrm{He}$ is the Creator, then one sees the presence of God in every human culture. The presence of God among each group helps people to recognise worthy social realities.

Since the range of this study is very broad I have limited my reflections to the use of medicinal plants within traditional medicine among the Manianga of Zaire. Many studies have been done on the subject of traditional medicine, but without a great emphasis on phytotherapy (therapy using plants) - even though it is viewed as the most common health-care therapy. With this perspective in mind, more emphasis has 
been put on the nganga bikola (healers who use plants only) than on the other nganga (diviners and healers) whose use of plants is limited because they concentrate on the supernatural forces within the healing process. However, this emphasis is only on the nganga bikola with both traditional and Christian orientations within the church.

This article deals briefly with the following: Introduction to the Manianga of Luozi; the pre-Christian Manianga approsch to healing; the Western missionary approach to the Manianga; the Manianga healing practice and the Cirristian influence; and the Church and its mission. I hope that this analysis will give some insight into healing among the Manianga of Zaire.

\section{INTRODUCTION TO THE MANIANGA OF LUOZI}

Zaïre is a huge country with 11 provinces. In each of these provinces there are many tribes, each with their own language. However, in the province where the Manianga live all the tribes are able to communicate by using one language called kikongo, even though it has different dialects.

Ethnically, the Manianga belong in the Bakongo, which region occupies 'North Western Angola, Western Zaïre, Cabinda and the western part of the Congo Republic: (the site of the ancient Congo Kingdom) (Janzen 1978:xix). The name Manianga has its origin in the movements of the Bantu people from the north of the African continent to the south. According to some historians and anthropologists, the Bantu groups from Egypt established the Congo Kingdom on the right bank of the Congo-Zaïre river. The Congo groups found it impossible to cross the river there and travelled to the south of Kalunga, where a river-crossing was easier. One part of the Bantu peoples, however, refused to migrate, electing to settle on the right bank of the river. The departing people mocked those who stayed behind and called them Ba niangwa (the forsaken people) from the verb 'niangwa' meaning to forsake, or to banish (Zamenga 1985:11).

The name Manianga is common to all people living on the left and right banks of the Zaïre river. Therefore, they are differentiated by the name, adding a preposition to Manianga to indicate the specific context, such as Manianga ma Luozi ('ma' is a preposition which means 'of' - thus Manianga of Luozi). One has to remember that the additional name was given to indicate the geographical situation.

The Manianga as a tribe is divided into a number of clans, such as: Mazinga, Sundi and Bwende. These clans are found not only in Zaire but also in the Republic of Congo. Jacobson (1979:23) affirms that 'the Kikongo-speaking peoples include, besides the Congo proper, the Sundi, Bwende, Kamba, and Dondo, who all occupy the border area between Zaïre and Congo-Brazzaville'.

These tribes have a matrilineal system. The children belong to the clan of the mother. The children have different responsibilities towards the maternal and paternal clan. In the maternal clan, children are called bana bankazi - nephews or nieces. 
They are expected to assume leadership of the clan when the uncles reach a certain age. The bar.a bankazi have to support their relatives financially and materially. They are supposed to learn the Kikulu kia kanda - the tradition of the clan - because they will otherwise be unable to lead the clan properly. They inherit property and political power from their uncles.

Although the children belong to the maternal clan, this does not preclude their exercising some responsibilities towards the clan of the father. In the paternal clan, the children are called bana bambuta (this means all the children born in the paternal clan without distinction of age or sex). All have the same privileges. They have to support their paternal uncles and aunts in everyday life, take responsibility for social harmony in the clan and take the initiative of reconciliation between members of the paternal clan in cases of quarrels and disappointments. Should serious conflict occur among members of the clan, the bana bambuta have to organise meetings to solve the problems, and impose fines on the guilty members. Only the bana bambuta have the privilege to enter into direct contact with their batata - deceased ancestors (Zamenga 1985:55).

\section{THE PRE-CHRISTIAN MANIANGA APPROACH TO HEALING}

As I have stated above, the quest for health care has been a major concern for the African people. In this regard Staugård (1985:5) states that 'the search of health, defined as a state of total physical, mental and social well being, has throughout history been at the centre of the minds of human beings in all cultures'. Though people have used their knowledge to discover medicinal plants around them, one cannot deny that God has been involved in the process of health care.

Generally plants have been considered by human beings as both food and medicine. In this regard Dokosi (1988:8) states:

However, man and women of the earliest ages started looking around their habitat. They made use of plants from which they prepared certain remedies, and from these they determined their efficacy by trial and error. These first experiences showed that plants, and certain minerals and animals, effected the healing which was required of them, and as a result a trust of that curative source developed. Consequently, the use of medicinal plants has been accepted universally. The use of medicine derived from plants was practised in ancient civilisations such as Egypt, Greece, Persia, Rome, China, Africa, India and America. These remedies derived from plants were very important to our ancestors who did not have any other means of treatment (my translation). 
Thus, previous generations understood the nature and content of phytotherapy. All around them 'was strength and power, and all trees, herbs and also some other substances could each possess a certain strength which was known, controlled and used in the healing of diseases' (Mbama 1984:4; my translation).

\subsection{Origin of disease}

The ancient Manianga thought that disease was like a string which ndoki - wizards tied to anybody who fell out of favour as a result of disobedience to the wizard's will or that of the clan. Thus, disease was considered to be a form of punishment (Fu-Kiau 1968:37). Disease was often foreign to the community and a means had to be found to remove it.

The Manianga believed in two principal causes. Disease could be from God, in which case it was called kimbevo kia Nzambi - disease from God. It could, on the other hand, be caused by the ancestors or by living people. In this case it was called kimbevo kia bantu - disease from people (Mbelolo 1986:27). This leads us to assume that the ancient Manianga did not know about microbes as the cause of disease.

\subsection{Healing process}

In ancient Manianga society, healing was the concern of the whole community. The members of the community had to search for the cause of the illness and they were the only ones who knew, together with the medical specialists, the procedure and the means by which the disease was to be cured.

With regard to healing as a common concern, the members of the community developed a certain form of empirical education. Everybody in the community was supposed to know something about the use of medicinal plants. In this respect Mbelolo (1986:26) states:

In the domain of traditional therapy, knowledge related to medicinal plants was imparted empirically from one generation to the other. The old people taught the young which kinds of medicinal plants to use in case of a headache, toothache, attacks of diarrhoea, et cetera. The acquisition of knowledge was simultaneously individual and collective. Each child of the clan received this knowledge from his/her relatives and all the children of the same age had to be familiar with important elements concerning the balance of human health care (my translation). 
This empirical method helped, and still helps, the people to treat and cure some diseases without consulting the specialists. It was not a question of having access to such medical knowledge only by specialist training.

Yet some people were trained beyond the scope of general empirical knowledge. Such training took place at a traditional school which was called Lemba or kinkimba by the Manianga of Luozi, and Kimpasi by the other Manianga groups. At Lemba the students were initiated. They were taught all the therapeutic methods and about some important social matters such as kinzonzi (palaver or law), kinganga-buka (curative medicine), kinganga-ngombo (discovery of the hidden causes of disease), all of which were a mixture of psychology, psychiatry and psychoanalysis (Mbelolo 1986:31). All the medical specialists, nganga-bikola (herbalists), nganga-ngombo and nganga-nkisi (healers and diviners), were taught at Lemba to be the guides of the community and to participate at all levels of social care and development according to their training. Anyone who wished to become a nganga-bikola (herbalist) was required to have a deep knowledge of makaya (leaves) and minti mia mbukila (medicinal plants).

Traditionally, the nganga-bikola was a doctor who could treat patients and a pharmacist who could prepare medicines and knew their dosage. The nganga-bikola could prescribe a wide variety of medicines which were largely derived from plants, animals and minerals. Medicine was applied to or injected into the body of the patient by tattooing. Each nganga-bikola specialised in the treatment of a number of diseases. The nganga-bikola did not necessarily need to use divination or spirit possession to heal the patient. He/she generally used bilongo - medicaments (Kimpianga 1980:64). The nganga-bikola used to cure patients with medicinal plants found in the immediate natural environment and about which he/she had proven theoretical and practical knowledge. He/she was therefore trusted by the community because of his/her abilities (Mbelolo 1986:33). Thus these healers had a high status and played an important role in the social life of the community.

The preparation of the medicine depended on the availibity of the relevant plants in the environment concerned. There were some plants, for instance, used for treating diseases, which were found in one place but which could not be found in another. In such a case other plants were served to heal the disease there. It was noticed that one plant could be used to treat many diseases (for instance the leaves of the nti wamfudi the cotton tree - which were used to treat both wounds and asthma), or one disease could be treated using a combination of many different medicinal plants - for example asthma could be treated with banana leaves, mfumu a nseke, and the roots of munkwisa (Lubaki, personal interview). The results of the treatment depended on the seriousness of the case and the abilities of the nganga-bikola. In cases where all attempts at healing were unsuccessful, the following proverb was recited: Nkole yakanga Nzambi 
kayilendi kulwa kwa muntu ko. This means that when someone has been enslaved by God, nobody can redeem him/her (Bahelele 1956:59). The message behind the proverb was that God was the ultimate healer and he alone could do what human beings could not.

Human beings have limited power, and the nganga-bikola recognized that he/she was subject to God. As a human being, the nganga-bikola was not capable of acting like God - the Supreme Being - in matters concerning healing. It is from this understanding that the Manianga distinguished the kinds of diseases which were mentioned previously. The nganga-bikola used proverbs in which God was recognized as the great healer and he had to be linked to the healing process by means of invocation. Included were the following: Nzambi kutulu kabukilanga (God treats when someone is asleep); buka mu kati yabuka kumbazi (treat inside and he/God will treat outside (Bahelele 1956:60). As specialists, the nganga-bikola associated God with the healing process.

From the above, one should understand that the Manianga believed and believe in God, who is commonly perceived to be the Supreme Being, transcendent and the Creator. $\mathrm{He}$ is the source of life that is experienced in the community (Nyamiti 1987:1). The concept of God is 'expressed by directly stating that God created all things through giving Him the name of Creator and through addressing Him in prayer as the Creator or Maker' (Mbiti 1970:45). The traditional concept of God was well known by the Manianga. In this regard God is called Nzambi Mpungu (Nzambi = God - Supreme Being; Mpungu is from the verb mpunga - to be almighty; - thus God the Almighty); Nzambi Mpungu Mayanama (Mayanama is from the verb yanama - to spread over; thus Mayanama - to spread himself over; God Almighty spreads himself over everything above and under the earth); Mpungu Tulendo (Tulendo from the verb to be able; lendo = power; thus God is Almighty because of His power); Mpungu Ngolo (ngolo = strong; thus the Almighty is strong). All these names meant that the Manianga perceived God as the Almighty, above everything, powerful and strong (Bahelele 1977:76).

\section{THE WESTERN MISSIONARY APPROACH TO THE MANIANGA}

The Manianga were evangelised by two different groups of missionaries: Roman Catholic and Protestant. However, in this paper I would like to focus on the Protestant missionaries, especially those of the Swedish Mission, because I am a member of the Church which was established by that Mission.

One cannot deny that the missionary's presence in Africa brought many changes at all social levels. The Swedish Protestant Mission called Svenska Missions Förbundet 
(SMF) was founded by an amalgamation of a number of associations and mission societies in 1878. It originated during the popular spiritual revival of Sweden during the latter half of the nineteenth century (Dalmalm 1985:102). The spiritual revival was a reaction against the monopolizing of the Church by the Swedish state.

According to the Revivalists, the conditions for becoming a Christian were to be born again (Jn 3:3), to be a committed Christian, to forsake one's previous life without God (Eph 2:12), and to live according to the the norms and the morals of the Christian community which had been formed by those who had been born again (Dalmalm 1985:102). Therefore the general conception of Christians was that all Christians born from the spiritual enlightenment should be able to read, understand and put into practice the Word of God. This atitude was shared by the missionaries in the Congo and it influenced their approach to mission work (Dalmalm 1985:102).

The Svenska Missions Förbundet committed itself from the start to the proclamation of the Good News (the message of the repentance of sins, conversion, and becoming committed Christians). Members of the association foilowed the words of Jesus Christ to his disciples: 'You will be my witnesses not only in Jerusalem but throughout Judea and Samaria, and indeed to earth's remotest end' (Ac 1:8). From Sweden they spread the good news throughout the world through the power of Jesus Christ, as he had said: 'All authority in heaven and on earth has been given to me. Go, therefore, make disciples of all nations ....' (Mt 28:18-20). Inspired by the revival, Swedish Christians went out to proclaim the good news of salvation to the countries near Sweden, such as Finland, Russia and the Baltic region. Afterwards, mission work started in Africa, particularly in the Congo (Palmaer \& Stenström 1960:3).

The missionaries, being Christians from the revival, emphasised that their mission was mainly the prociamation of the good news to the people of the Congo. Missionary proclamation was aimed at the conversion of the people to Christ (by their forsaking all their old and heathen ways - for example, fetishes and belief their in their ancestors), and the repentance of their sins, to become committed Christians in the Church. Dalmalm (1985:104) comments that 'the missionaries thought that the Christian community arising from their mission work should be autonomous, responsible itself for evangelising its own people' (my translation). The Svenska Missions Förbundet achieved its goal of building a local church in the Congo. The Church is growing spiritually, economically and materially. It is self-reliant, although it still receives some aid from the Swedish Mission.

The missionaries proclaimed the Word of God to the people. Wishing to build a strong church, they drew up principles to be observed in daily Christian life. These principles (as can be seen below) helped the missionaries to convert people to Christ. However, the task was not an easy one. Kimpianga (1988:36) comments on the principles as follows (my translation): 
[I]n order to strengthen the Christian mission, the Interior Order Settlement was drawn up in 1890 . This was drawn up on the basis of the Ten Commandments of the Old Testament and on the moral teaching of the New Testament. The missionaries drew up some rules rejecting customs and disqualifying practices and beliefs which were in opposition to those in the Western world. For instance, the practice of fetishism (nkisi), wizardry (kindoki), the mummification of the dead, the practice of ordeal/ritual (nkasa, practised in traditional medicine) and polygamy were considered sins.

Through their ministry the missionaries prevented Christian involvement in what they considered to be heather practices and discouraged people from believing in them. Here one can see a negative attitude to (or disapproval of) the sociocultural practices of the people, especially their healing methods.

Can one condemn and totally reject the attitude of the missionaries toward the sociocultural norms of the Manianga? I suggest that, on the one hand, the work of the missionaries can be supported. The fact is that there were a number of practices which were not favourable to human development; practices which were, by implication, destructive to society. When a wife lost her husband, for instance, she had to stay in a room with the decomposing corpse of her late husband for a number of days as a demonstration of love and loyalty, crying continiously as a sign of mourning (Niamba, personal interview). This was one of the socio-cultural laws that put great pressure on women oppressing them. In this regard, the missionaries were right to condemn the mummification of corpses, because it perpetuated the oppression of one part of society (women) by another (men). Another example concerns the phenomenon of witchcraft and associated therapy. All the suspects were put to the test, the nganga (diviners and healers) being the main actors in the therapeutic process. The nkasa - ritual - was considered the real test for determining exactly who the ndoki was. Before the suspects were put to the test, they were asked to fast for a day. They were not allowed to eat more than, say, bananas or peanuts. At the right time, the suspects had to drink about two litres of nkasa (a liquid obtained from the bark of a tree). After the nkasa had been drunk, overseers were appointed to supervise the suspects to prevent cheating. Those who had drunk nkasa were not allowed to go to the toilet for the duration of the day. The one whose need was the greatest and who went first was automatically accused of being ndoki, and whoever had managed not to go to the toilet passed the test and was honoured by the whole community (Dalmalm 1985:81-82). Many innocent people were killed because of the belief in kindoki and the resulting ordeal. 
Unfortunately many of the old and wise people were often accused of being ndoki because of the general conception that old people were ndoki. The young people accused them of having caused any unexpected deaths which occur-red in the community (Niamba, personal interview).

On the other hand, the missionaries are to be criticized because some of their judgements concerning Marianga beliefs and practices were unfair. For iristance, the traditional healing process, even the work of nganga-bikola which was limited to using makaya ma nsi (plants, herbs, etc), was rejected in its totality. The missionaries overlooked the fact that healing with plants served the people and occupied an important place in their history of health care. Traditional healing was condemned as being based on superstition because of the presence of the nganga who were viewed as heathen and witchdoctors. Dalmalm (1985:108) states:

[T] he missionaries believed that there were no traditional treatments without the intervention of fetishism, but that patients were treated without the healer being associated with the belief in and the adoration of he nkisi (fetishes) and gods. Their presence was viewed as a sign of paganism and of evil forces. From that perspective, all traditional healing activities were condemned (my translation).

It seems as if traditional medicine was rejected by the missionaries - not only because of nganga activities, but also because of the destructive effect of the medicine on the organic systems of the patients because of certain healers' lack of knowledge about the correct dosages.

Despite this, the missionaries should not have banned traditional medicine totally. As a result of their ignorance about traditional healing, the missionaries tended to warn Christians about the dangers they would court in accepting the heathen healing practices of the nganga. A Christian should find healing at the hospital and in Christian prayer. To seek it somewhere else is not compatible with the Christian faith. Believing in God - Nzambi - meant believing in Western medicine with all its natural explanations of disease' (Dalmalm 1985:109).

In their missionary activities the missionaries built hospitals to serve the whole community and as a means of saving many lives. The modern hospitals were sufficient in themselves and, according to the missionaries, were not supplementary to traditional medicine. That is why Christians had to reject tradition and opt for Western scientific healing methods. 
One cannot deny that modern medicine had and has its importance for the Manianga. Modern medicine was and still is a supplement to traditional medicine. Modern medicine is an extention of the traditionial by virtue of the new technological methods which have improved medicine as a whole. However, 'to oppose traditional medicine in favour of modern medicine is anti-scientific because, from the first to the last, there is not an opposition, but rather an evolution. This is due to the use of modern instruments which allow for improved, more precise details about the diagnosis, the quantification of data, the dosage, et cetera. In summary, modern medicine is not something different; it is rather, traditional medicine ameliorated and improved by means of its scientific equipment' (Mbelolo 1986:30; my translation).

Modern medicine being supplementary to traditional medicine, the Manianga believe that both should work together for health care without contradiction. It is from this understanding that the Manianga used and still use these two types of medicine simultaneously to prevent and cure diseases. All who practise medical treatment are mimbuki - healers - in the eyes of the Manianga.

\section{MANIANGA HEALING PRACTICE AND THE CHRISTIAN INFLUENCE}

At this point, I would like to focus my description of the Christian influence on the traditional concepts of God and the ancestors within the healing process on the two groups (traditional Christian and Christian healers) of the nganga-bikola.

\subsection{God within the healing process}

We have seen that the Manianga generally perceived God as the Creator of everything. This understanding does not exclude the traditional and Christian maninangan phytotherapist. God is exalted above all human beings and acts from above, protecting and securing people below.

The general belief of the Manianga prior to Christian mission work was that God was in contact with people through the ancestors and vice versa. In this regard the representatives of the living community, especially the priests (nganga) or chiefs also had the privilege of ertering into direct contact with the ancestors for purposes of securing the well-being of the living community. Here, the representatives served as mediators between the living and the deceased. The purpose of this mediation was to plead with the ancestors. The ancestors, in turn, were mediators between the people and God, and they intervened and pleaded with God concerning matters such as illness or death among people. God was perceived in his actions and being as Creator of the ancestors and of their spirits. God was not understood in the trinitarian perspective of God the Father, the Son and God the Holy Spirit, as is the case in Christianity. That old view still exists among traditional Christian healers. Their belief is that once one invokes God the Creator, one will be answered by him. The emphasis on God leaves the 
impression that traditional Christian healers bring the old religious perspective into their Christian belief. It seems that the biblical revelation of God and his incarnation in Jesus Christ and his manifestation in the Holy Spirit have not had a very great impact on their healing practice. This could be explained by the fact that the traditional Christian healers understond and were familiar with the concept of God long before Christian missionary work.

In considering God as the Supreme Being, the traditional Christian healers also believe that $\mathrm{He}$ can be the source of disease. When somebody does not respect the community's rules, the ancestors, being spirits and under the control of God, could be angered and cause disease to the disobedient (Nsonsisa, personal interview). In this regard, the healing process varies according to the beliefs of healers. For instance, the nganga-nkisi or nganga-ngombo would visit the graves for the healing ceremony, but the traditional Christian healers would proceed differently. Lubaki (personal interview) who is a healer said: 'My concern will be to pray to God and ask him to plead our cause with the ancestors so that their anger towards the disobedient person might be appeased. There is no mystical ceremony'. This remark implies that the ancestors can be appeased through prayers rather than proceeding to the grave as we have seen previously. Despite the intervention of the nganga, God is seen as the Great Healer whatever the illness and the origin of medicinal plants. God is praised and invoked by traditional Christian healers without sacrificial rituals or magic.

With regard to the second group, the exclusively Christian healers, there is an emphasis on the Holy trinity, God the Father, God the Son and the God the Holy Spirit in their healing practice. However, this notion is featured in the preachings and the doctrine of the Church. The Holy Trinity is included in all prayers and believed to be the true means of involving all the persons of the Holy Trinity in the interactions within the healing process. In so doing, the exclusively Christian healers believe that there is a transcendental participation and intervention of the three persons on the behalf of the living community. However, the Holy Trinity is believed to be the genuine source of revelation of medicinal plants. There is no other source which helps them become what they are within the living community. Therefore, there are more Christian features in the practices of the exclusively Christian healers than there are in the practices of traditional healers.

The exclusively Christian healers believe that God can also be the origin of illnesses. This is the case when a patient has committed sin. Such a patient should then confess his or her sins before being treated with medicinal plants. Confession is seen as spiritual healing before one is treated with medicaments. Withouc that spiritual 
healing, the medicaments cannot work as they should for a normal disease (Nsimba, personal interview). Through this approach the patient expects to obtain all blessings which come from God the Father and God the Son through the power of the Holy Spirit.

\subsection{Ancestors within the healing process}

The general conception among many African tribes, and particularly among the Manianga, is that the dead are not really dead. They continue their lives in another world. Death can be understood as the way which leads someone from the visible world into the invisible one where he/she will become an ancestor without forsaking the living community. Nyamiti (1982:46) explains that 'death is the initiation into another mode of being. After death, we remain human but with new qualities. Death changes our status without destroying our humanity'. Given this understanding, the traditional Manianga like to put things such as dishes, bottles, forks and knives on the grave of the deceased, signifying that the deceased will continue their lives; it is necessary to secure their future lives by providing them with some of the things they used in their former life.

If death is understood in this way there are various possibilities for the deceased to play an important role within the living community. In this regard, the traditional Christian healers believe that the ancestors are fully human although they live in another world. The traditional Christian healers derive power from God, the ancestors and their spirits to help them succeed in the healing process. However, despite the prominence of God, the ancestors and their spirits in the healing process, this should not lead one to the conclusion that the traditional Christian healers ignore the existence of Jesus Christ and the Holy Spirit. The Trinity is seen as sharing in the role of the Creator. One could say that traditional Christian healers accept the Holy Spirit without distinguishing between the personae of the Trinity.

In the light of these beliefs it is conceivable that there is a serious conflict within the Church. We see the ancestors playing the important role of mediators between the living community and God. One sees, through this conception, the integration of the ancient methods of the nganga into the Christian belief and practice without substantial change. The inclusion of the ancestors' mediatory role leads to think about this question. How could a Christian interpret the mediation of the ancestors while the Bible insists on Jesus Christ as the only mediator? This question will be answered as we progress in this paper. 


\section{THE CHURCH AND ITS MISSION}

\subsection{An overview of the biblical understanding of disease and medicinal plants}

\subsubsection{Concept of disease}

As we have seen, the Manianga have their own understanding of disease, but this does not mean that their beliefs are in complete opposition to the thinking of other Zairian groups. The general belief is that the Supreme Being - as well as the living, the deceased and the evil spirits (individually and corporately) - is often the cause of illness among the living community.

With regard to the biblical perspective, the origin of disease is linked with the Christian history of God's creation. This could be interpreted as meaning that disease entered the world when the first human beings committed sin. Therefore disease was seen as God's punishment upon them. Tenney et al (1984:86) comment that 'human beings have been victims of disease since the day on which the Lord chased Adam and Eve from the Garden of Eden - Genesis 2:19' (my translation). Hence, disease has been regarded as God's punishment because of the presence of sin among his people.

In this respect, Buttrick (1962:848) comments that 'the general view of the Old Testament is that disease is sent by God as a punishment for transgression or as an expression of his wrath - cf Exodus 4:11, Deut 32:39'. Although the judgement of God was viewed as the real origin of disease, there were other origins. Buttrick (1962:848) continues: 'other views ascribed the origin of disease to the work of the adversary (Job 2:7), or to what were called spirits of dumbness (Mk 9:17) or uncleanness (Mk 9:25). Jealousy on the part of others (Job 5:2) and self indulgence (Ec 37:30-31) were also held to be causes of diseases'.

From the Old to the New Testament, the perception of disease as God's punishment shifts to a new understanding and interpretation. Disease was no longer considered as destructive or punitive (individually or corporately). Disease came to be seen as 'divine education, restoration, glorification, with redemptive value for its link with the cross of Jesus Christ for human beings' salvation' (Pirot, Robert \& Gazelles 1957:967; my translation). Therefore, Jesus Christ's ministry brought new insights about disease. Mills et al (1990:217) state that 'the penal understanding of sickness survived into New Testament times but was significantly modified by the teaching of Jesus (Jn 9) where the first recorded sermon indicates that his earthly ministry was closely tied to the needs of the frail and feeble of body and spirit (Lk 4:18-27)'.

With regard to the Old Testament understanding of disease, one could say that the notion of disease as originating from God and from an evil spirit is a very old one. This idea is similar to that of the Manianga, who also believed that God or natural spirits were the cause of disease. 
Although God was viewed as one of the origins of disease, the Manianga attributed the highest position - that of the Great Healer — to God. In this regard, the Heorews also believed that 'despite the link of disease to God - the vera causu of disease - the whole healing process lay in his hands. God was the great physician of his people (Ex 15:26) and it was their duty to look to him for relief ...' (Hastings 1900:321). This reliance on him indicates the trust that the people had in the use of medicinal plants that God had created for their use. This leads us to study some of the impli-cations of their use among the Hebrew people.

\subsubsection{Medicinal plants}

As Hastings (1900:208) said, 'When we examine the Scripture on the subject of healing we see that God is a Healer and it is reasonable to conclude that $\mathrm{He}$ is the source of all true healing'. Hence, as the Creator of the universe, God has power over everything and can use it to provide security for his people. In the Bible one reads that God created everything, including the plants (Gn 1:11;2:9). According to the Bible, the plants were created so that they might be considered to be food by the human race ( $\mathrm{Gn}$ 1:29; Ezk 47:12) and also to serve as medicine (Ezk 47:12; Rv 22:2).

The Bible does not give us detailed references about medicinal plants within the Hebrew context. But from the passages cited above, one understands that plants were created for the purpose of saving the lives of human beings. That is why plants are part of human history, in the sense that they served and still serve us within that context. No nation in this world is excluded from the use of plants as food and medicine.

Previously we have seen that the ancient Manianga used plants, mineral and animal substances as medicines.' The same was true of the Hebrew community. Tenney $\varepsilon_{t}$ al (1984:94) states that 'in biblical times, medicaments were from mineral and animal substances; herbs, wine, fruits and other vegetable substances' (my translation). Here the vegetable, mineral and animal substances were very important elements in the building of the human organism.

Within the Hebrew community there were quite a number of fruits which were considered medicinal. Hence, "the prickly pear was considered one of the best fruits (Mt 7:16) and attributed to it were healing properties for wounds, ulcers, et cetera; (Westphal 1956:437). Since the medicinal plants were regarded as having been created by God, the general belief was that they were truly God's gifts to his people.

In their common understanding, 'the ancient Hebrews appear to have employed herbs and vegetable substances of medicinal virtue ... purely for general therapeutic or culinay purposes' (Seybold et al 1981:13). In addition, among the plants with reputed medicinal properties we have some such as the oil and the aromatized wine which 
served as dressings on wounds - Luke 10:34' (Westphal 1956:88; my translation); 'the lenitive lotions of oil and herbs were rubbed on the patients and the wine mixed with myrrh alleviated pain' (Tenney et al 1984:94; my translation).

Despite the importance of medicinal plants, the Hebrew community nevertheless believed that the patient was guilty before God and that disease was a punitive measure. This attitude originated in the link between sickness and sin. In this regard, the putient sought a good relationship with God by confessing his/her sins. An illustration from the life of king Hezekiah confirms this belief. King Hezekiah suffered from a terminal illness and received a message from God that he was gcing to die. The king complained to God in prayer and said: 'Lord, remember how I have lived before you, faithful and loyal in your service, doing always what was pleasing to you' (2 Ki 20:3). This lament by the king could be understood to mean that he was guilty before Gnd, and that the consequences of being a sinner were God's punishment. By God's grace and mercy, king Hezekiah was promised healing because God had heard his prayer. God then sent the prophet Isaiah to tell the king's attendants that they should prepare a fig plaster and put it on his boil (inflammation). Verse 7 states that 'when it was made and applied to the inflammation, Hezekiah recovered'. Another illustration is that of Rachel. In Genesis 30:14-16, we read that 'during the wheat harvest Reuben entered the field and found mandrakes, which he brought to his mother Leah. Rachel said to Leah, 'Please give me some of your son's mandrakes ...' Why did Rachel need the mandrakes? She needed them because she hoped to find a remedy for to her barrenness in the mandrakes - 'plants which were believed to produce fertility and were used as love-charms' (Jones 1906:31).

These two illustrations help us to see the importance of medicinal plants within the ancient Hebrew community. One cannot deny that healing resulting from the use of medicinal plants appears to be God's plan among his people. He created certain substances for specific purposes and uses by human beings.

\subsection{The Church and the healing ministry}

In the Old Testament, healing generally was the responsibility of the Levites, who took responsiblity for all the health rules within the community. As Mills et al (1990:217) comment, "the book of Leviticus reflects the religious nature of disease and healing in the Old Testament. The priests were important figures in customs relaced to disease and healing. Prayers like Psalm 6 also indicate that ancient Israel's cult included rituals associated with illness'.

With regard to the New Testament, the healing ministry was considered one of the relevant preoccupaticns of Jesus Christ throughout his ministry (Mt 8:1-3, 14-17, 2832; 15:29-31; 17:14-20; Lk 5:17-26, etc). As revealed in his ministry, Jesus Christ had the power of God to heal all kinds of illness (Mt 9:35). The New Testament does 
not mention the use of medicinal plants but other elements were regarded as means of healing, such as the laying on of hands. However, Jesus Christ used also saliva, water, and soil (Jn 9:6) as curative elements in his ministry. These natural elements were empowered by Jesus Christ and they became useful for the purpose of healing. Scientifically, they did not have curative force to treat blindness. The striking fact is that the blind ware healed. This indicates the importance of the christological message and its effectiveness in the salvation of humanity.

It is from this biblical background of Jesus Christ's ministry that the Church derives its belief in healing as one of the central elements of its evangelical ministry throughout Manianga. The Church exercises a healing in the sense that it uses Christians who have the ability to heal patients through prayer. In this respect the believers see God as the great healer and the Church as a healing institution. God is the only one who can empower his children within the Christian community to exercise this healing, which must conform to the biblical model. The Church believes that the healing ministry is linked to prayer and hospitals as means of healing. However, it does not emphasize the use of healing to the extent that the other charismatic and pentecostal churches of Zaïre do.

It needs to be stated that some church members have doubts about whether the medicinal plants are important enough to be added to the Church's healing ministry. Although the Church agreed to introduce medicinal plants to its healing ministry, ministers and other intellectuals are still asking themselves whether the practice should be considered as a gift of the Holy Spirit and included in the Church's healing ministry. On the one hand the ministers and intellectuals cannot be blamed, because they were influenced by the Christian Swedish Mission, which disregarded the value and the success of traditional medicine. On the other hand, the ministers and intellectuals could be challenged to recognize that the gospel as the 'good news cannot destroy everything which is good, honest and beautiful that the people take from their character and culture' (Luzbetak 1963:49; my translation). This is the challenge to the Church leaders with theological training - to apply the message of Jesus Christ within the context of the healing ministry and cultural practices. As medicinal plants are God's creation and are useful for human beings, ministers and all other Christians should demonstrate their value through their attitudes, mission and evangelism.

We have seen that there are two groups within the Church concerning healing. Thus the Church should take into consideration all the groups of healers within its fold, with both traditional and new beliefs in the Supreme Being as part of the healing process. With regard to the old and new beliefs among the healers within the Church one sees a degree of tension. This is caused by the still deep-seated belief that the 
ancestors are associated with God, and as such, function as real forces in the healing process. However, the Church does not officially recognize the belief in the ancestors. According to the Church's doctrine, Christians are forbidden to believe in the deceased. This understanding has been inherited from the Swedish Mission to the Manianga and has its foundation in biblical teaching.

As we have already seen, there is some confusion about the role of Jesus Christ and the Holy Spirit and that of the ancestors in the healing process. In this regard the ancestors, to a large extent, absorb the place of Jesus Christ in the healing process according to the traditional Christian healers. The Church does not necessarily rely on this understanding in the healing process but it should not directly condemn this practice.

This old understanding could be considered a very good opportunity to enter into new order through the revelation of Jesus Christ. At this point a dialogue should be established with those who still believe in the ancestors. However, as Pobee (1979:80) suggests, ' $\ldots$ it should be undertaken and achieved through dialogue between Christian faith and African culture. But it must be a dialogue with a challenge to conversion if it is not to remain sterile talk'. The biblical message could be used to explain to the traditional healers that the Manianga, before the Christian mission, had the right to. associate the ancestors and their spirits within their social context by virtue of the fact that those realities were evident and effective in their context. Their belief was that God used those means to reveal himself to his creatures, especially in times of crisis. Nowadays God reveals himself in Jesus Christ, the Lord and Saviour, so that the world may be saved. This implies replacing the role of the ancestors and their spirits by Jesus Christ and the Holy Spirit. In the new order, Jesus Christ is the real mediator (Heb 12:24) for the new covenant between God and human beings. Therefore, the healer could practise healing through the power of the Holy Spirit who has been given to us (Ac 1:8).

The Church has the task of demonstrating the creative role of God by showing that the medicinal plants have natural strengthening and curative properties. The human empowering of medicinal plants does not change the physiology and the constitution of any leaf, herb or plant. This empowering has to do only with the level of belief. The role of creation belongs to God, who placed in the plants the curative elements which are necessary for human beings. Therefore, the traditional Christian healers should continue with their treatment of patients within the Manianga context because their actions and service are linked to the salvation of humanity. This demonstrates the continuation of the healing ministry of Jesus Christ among his people, although he did not use medicinal plants Himself to treat diseases. 
This is the challenge to the church - to take up the issue of medicinal plants seriously within its healing ministry. The church should accept all phytotherapists at the same level and allow them to contribute to human salvation. All the therapists from the different traditions should collaborate without misunderstanding. This will require sound leadership from the Church.

The church is also responsible for reminding its ministers not to ignore the therapists, so that they may use their abilities to obey the Supreme Being, God, and follow the example of Jesus Christ who healed without pride, demonstrating the glory of his Father. The Bible is the only source that will help the nganga-bikola to recognize their lack of understanding about concepts such as God, Jesus Christ, the Holy Spirit, the deceased, and so on within their healing practices.

Despite the technological growth of modern medicine, its roots always have something to offer, and this is why both types of medicine should remain linked. What the scientific community of Manianga should bear in mind is that modern medicine does not contradict the traditional, its foundation. This implies that collaboration should exist between the healers within the church and the modern medical community. In collaborating it would be important for all practitioners, modern and traditional, to be aware of their limitations in the healing process. For the reaity is that there are some diseases which are treated by phytotherapists which could be treated by medical doctors, and vice versa.

\section{Works consulted}

Bahelele, K N 1956. Kinzonzi ye ntekolo andi Makundu. Kinshasa: Cedi. 1977. Lusansu ye fu bia nkongo. Kinshasa: Cedi.

Brookmar:-Amissah, J 1984. African culture and Christian theology, in Ngindu Mushete, A (ed), The mission of the church today, 139-163.

Buttrick, G A et al 1962. The interpreter's dictionary of the Bible, Vol 1. Nashville: Abingdon Press.

Dalmalm, $\AA$ 1985. L'église à l'épreuve de la tradition: La Communauté Evangélique du Zaire et le kindoki. Paris: Editaf.

Dokosi, M O B 1988. L' homme préhistorique: Premier herboriste. Contact 24, October, 8.

Fu Kiau, K B L 1968. Kindoki ou solution attendue: Autour de prophétie, médicine, herbalisme et sorcellerie en Afrique noire. Kumba: Corsla.

Hastings, J et al 1900. A dictionary of the Bible. New York: Charles Scribner's.

Jacobson, W A 1979. Red-White-Black as a mode of thought: A study of triadic classification by colours in the ritual symbolism and cognitive thought of people of the Lower-Congo. Uppsala: Act Universitatis Upsaliensis. 
Janzen, J M 1978. The quest for therapy in Lower-Zaïre. California: University of California.

Jones, A 1906. The Jerusalem Bible. London: Darton, Longman and Todd.

Kimpianga, M 1980. Les Religions traditionnelles Africaines et l'Evangile, in Semaines Théologiques de Kinshasa (Actes de la dixième semaine théologique).

— 1988. L'impact du Christianisme au Manianga 1880-1980. Kinshasa: CVA.

Luzbetak, L J 1963. L'église et les cultures: Une anthropologie appliquée pour l'ouvrier apostolique. Bruxelles: Ed Humen Vitae.

Mbama, A 1984. Mouvement de la guérison dans l'Eglise Evangélique du Congo. Dissertation de Licence. Faculté de Théologie Protestante de Yaoundé.

Mbelolo, Y M 1986. La recherche scientifique dans le processus du développement: Cas du C R P L. Bilongo 6, Décembre, 27-31.

Mbiti, S J 1970. Concept of God in Africa. Southampton: Camelot.

Mills, W E et al 1990. Mercer dictionary of the Bible. Georgia: Mercer University Press.

Nyamiti, C 1977. African tradition and the Christian God. Eldoret: Gaba.

Pirot, L A, Robert, \& Gazelles, H 1957. Dictionnaire de la Bible: Supplément. Paris: Librairie Letouzey et Ané.

Pobee, S J 1979. Toward an African theology. Nashville: Parthenon.

Palmaer, G \& Stenström, O 1961. Mavanga ma Nzambi mu Kongo: Nsamu wa S M F-M E S 1881-1955. Matadi: Imprimerie de l'E E M M.

Setiloane, M G 1976. The image of God among Sotho-Tswana. Rotterdam: Balkema. Seybold, K \& Mueller, U B 1981. Sickness and healing. Nashville: Abingdon.

Staugård, F 1985. Traditional medicine in Botswana: Truditional healers. Gaborone: Ipelengeng.

Tenney, M C, Packer J I \& William White, J R 1984. La vie quotidienne dans les temps bibliques. Miami: Vida.

Westphal, A 1956. Dictionnaire encyclopédique de la Bible. Valence Surhone: Imprimerie-Réunies.

Zamenga, B 1985. Luozi, 30 ans après. Kinshasa: ZABAT.

\section{Interviews}

Lubaki, B N, July 1992

Niamba, M, April 1992

ivsimba, D M, August 1992

Nsonsisa, Z, April 1992 